УДК 338.439.6:339.137.2:006.3.015.5(477)

DOI: $10.15673 /$ fie.v11i4.1550

\author{
Кордзая H.P. \\ кандидат технічних наук, доцент \\ кафедра маркетингу, підприємництва та торгівлі \\ E-mail: natela_k@ukr.net \\ ORCID ID: 0000-0003-3429-0483 \\ Єгоров Б.В. \\ доктор технічних наук, профресор \\ кафредра комбікормів та біопалива \\ Одеська національна академія харчових технологій \\ вул. Канатна, 112, м. Одеса, Україна, 65039 \\ E-mail: bogdanegoroff58@gmail.com \\ ORCID ID: 0000-0001-7526-0315
}

\title{
ІНСТИТУЦІОНАЛЬНА СТРУКТУРА ВІТЧИЗНЯНОЇ СИСТЕМИ СТАНДАРТИЗАЦІЇ ТОВАРІВ
}

В даній статті автор зазначає, що «цифровізація» бізнесу є об'єктивною необхідністю розвитку підприємства в умовах «Індустрії 4.0». Окреслено ймовірний перелік об'єктів цифррових трансформаційних процесів для підприємств харчової промисловості. Об'єкти цифрової трансформації згруповані в три блоки: інфраструктура забезпечення цифровізації, інформаційно-комунікативні системи та бізнес-процеси й системи управління. Виділено основні фрактори запровадження цифрових технологій на підприємствах харчової промисловості. Відзначено, що цифрові технології є платформою зростання ефективності системи економічної безпеки підприємства.

Автором сформульовані основні завдання системи економічної безпеки підприємства в умовах цифрових трансформацій. Визначено основні вимоги щодо створення відповідних умов забезпечення трансформаційних IT-процесів. Виділено структурні компоненти системи запровадження цифровізації системи економічної безпеки підприємства. Зроблено висновки щодо напрямів подальших досліджень в галузі забезпечення системи економічної безпеки «цифрових» трансформацій.

Ключові слова: економічна безпека, трансформаційні перетворення, цифрові трансформації, цифровізація, система, підприємство.

This work is licensed under a Creative Commons Attribution 4.0 International License http://creativecommons.org/licenses/by/4.0/

Постановка проблеми та її зв'язок з важливими науковими та практичними завданнями. Сьогодні, в умовах ринку, що постійно змінюється та трансформується, підтримка підприємством високого рівня конкурентоспроможності товару досягається шляхом корегування чинників, які є вирішальними для споживача при його виборі [1]. Одним 3 найважливіших чинників конкурентоспроможності є якість. Під якістю товару, як економічною категорією, розуміють відповідність властивостей та ознак товару вимогам і потребам кінцевих споживачів. Основна проблема, що виникла на сьогоднішній день полягає в тому, що більшість товаровиробників не приділяє належної уваги якості товарів, а деякі з них, взагалі, досягають своєї основної мети - отримання прибутку, шляхом економії на якості для досягнення зниження ціни та тим самим підвищення попиту. Так, останнім часом експерти неодноразово стали звертати увагу на погіршення якості більшої частини вироблених товарів. В умовах реалізації Україною торгівельної політики, відповідно до правил Світової організації торгівлі, така тенденція ставить під загрозу конкуренто- спроможність вітчизняних підприємств [2].

Отже, для вирішення питання підвищення конкурентоспроможності українських товарів необхідно переглянути підходи до забезпечення та контролю їх якості. А це можливе тільки за умови використання документації, яка нормує та регламентує правила виготовлення та координації контролю якості товарів, а також гарантують безпеку життя та здоров'я населення, захист довкілля. Стандартизація якраз і є тією сферою, яка виконує всі ці функції $[3,4]$. Систему стандартизації розроблено на вітчизняному ринку саме для регулювання якості товарів [5].

Саме завдяки стандартизації можна свідомо керувати економічною і технологічною складовою бізнесу, домагаючись випуску виробів високої якості, які будуть найбільш конкурентоспроможними на сучасному ринку.

Стандартизація - поняття комплексне, яке включає в себе багато аспектів, основними за яких можна назвати науковий, технічний, господарський, економічний, юридичний, естетичний й політичний. В економічно розвинутих країнах підвищення рівня 
виробництва, поліпшення якості товарів та поліпшення умов життя населення тісно пов'язані з широким використанням саме стандартизації, як гаранта якості та безпечності товарів.

Стандартизація представляє собою достатньо ефективний засіб ліквідування технічних бар'єрів у міжнародній торгівлі та виступає організаційнотехнічною основою економічного i науковотехнічного співробітництва між країнами.

Поліпшення якості та підвищення конкурентоспроможності товарів (процесів, робіт, послуг) можливе тільки на основі стандартизації. Вона дозволяє регламентувати вимоги до якості товарів, більш ефективно вирішувати проблеми спеціалізації, визначати раціональні способи виробництва товарів і переробки сировини, здійснювати управління якістю товарів у виробництві та сфері обігу [5, 6].

Сьогодні, в Україні, достатньо гостро постало питання якості й безпечності товарів, які реалізується через сучасні форми торгівлі, а саме через Інтернет-торгівлю, торгівлю через каталоги та інші. Адже реалізація цих товарів нині є безконтрольною, а це може ставити під загрозу здоров'я та іноді й життя споживачів. Правове регулювання показників якості подібних продуктів, у нашій країні, є зовсім відсутнім. Проблеми стандартизації в Україні в цьому аспекті майже не досліджені $[5,7]$.

Аналіз останніх публікацій по проблемі. Сьогодні, дослідженням Дослідженню питань, пов'язаних 3 конкурентоспроможністю товарів промислових підприємств, приділяється значна увага у науковій та навчально-методичній літературі. Зокрема, дане питання висвітлюється в працях таких науковців та дослідників як Дятлова В.В., Вознюк С.В. [8], Гарасим Й. [9], Нагорна О.О.[10], та інші. Однак подібних досліджень дуже не багато, а у сучасних умовах розвитку економіки України питання стандартизації товарів народного споживання є одним 3 ключових. Отже ця сфера потребує подальшого аналізу, що й зумовило актуальність і вибір теми дослідження.

Багато уваги питанням гармонізації нормативного законодавства та перспективам національної системи стандартизації і сертифікації приділяють державні підприємства, що безпосередньо займаються проблемами сертифікації і стандартизації, а також численні проекти (як національні, так і спільні із зарубіжними) та фонди, що проводять моніторінг ситуації $з$ даного питання. Останнім часом спостерігається посилення інтересу щодо проблем гармонізації стандартів на продовольство. Так, Оносова I.А., Литвинська С. , Терера В. та ряд інших вітчизняних науковців вважають, що гармонізація нормативної бази $€$ необхідною умовою забезпечення конкурентоспроможності держави на світових ринках харчових продуктів [11-13].

Формулювання цілей дослідження. Метою даного дослідження $є$ аналіз особливостей функціонування національної системи стандартизації товарів народного споживання як основи іiі конкурентоспроможності.

Виклад основних результатів та їх обгрун- тування. За визначенням Міжнародної організації 3 стандартизації (ISO): «Стандартизація - це встановлення і застосування правил з метою упорядкування діяльності у визначеній області на користь та за участю усіх зацікавлених сторін, зокрема для досягнення загальної всебічної оптимальної економіки при дотримуванні функціональних умов та вимог техніки безпеки» $[14,15]$.

Простіше кажучи, «стандартизація» - це процес встановлення та використання стандартів. Стандарт представляє собою документ, який має юридичний статус, та є результатом конкретних досягнень у сфері науки, техніки та практичного досвіду. Стандарти розповсюджуються на усі сфери життя та діяльності людини: науку, техніку, промисловість, сільське господарство, будівництво, транспорт, охорону здоров'я та ін. Усі стандарти систематично переглядаються і поновлюються відповідно останнім досягненням науки $\mathrm{i}$ техніки. Стандарти $\epsilon$ обов'язковими в межах установленої сфери їх дії, області та умов їх застосування.

Максимальне наближення законодавства України у сфері технічного регулювання, а саме стандартизації до норм СС сприятиме безболісному входженню на внутрішній ринок західних сусідів. Тим паче, що в умовах різкої переорієнтації із ринків збуту Російської Федерації на ринки Свропейського Союзу та інших країн, загострюється проблема невідповідності вітчизняних товарів європейським/міжнародним стандартам. У рамках економічної частини Угоди про асоціацію між Україною та СС акцент ставиться на гармонізації регуляторного середовища України з відповідними правилами та нормами Європейського Союзу. У рамках відповідних положень даної Угоди $[9,16]$, Україна та країни СС зобов'язались зміцнювати технічне співробітництво шляхом удосконалення нормативно-правових актів та регламентів, покращення інституціональної складової, що займається питаннями метрології, стандартизації, ринкового нагляду, сертифікації та акредитації, сприяння розвитку якісної, ефективної і взаємовигідної системи стандартизації, метрології, акредитації, оцінки відповідності та ринкового нагляду в Українi $[9,17]$.

31 січня 2016 р. на території України замість національних стандартів поступово впроваджуються європейські стандарти (євронорми). Про це йдеться в Угоді про асоціацію та наказі Міністерства економічного розвитку і торгівлі України №1493 [9, 18]. Також в Угоді йдеться про скасування Україною дії міждержавних стандартів - ГОСТ. Починаючи з 2014 р. більшість реформаторських зусиль у галузі спрямовується на дерегуляцію системи стандартизації: здійснюються кроки у напрямку адаптації українських стандартів до європейських. У цьому напрямку прийнято та внесено зміни у ряд законів серед яких: «Про стандартизацію», «Про скорочення кількості дозволів», «Про метрологію та метрологічну діяльність», «Про технічні регламенти та процедури оцінки відповідності», «Про державний ринковий нагляд i контроль нехарчової продукції» та інші. Нова редак- 
ція Закону «Про стандартизацію» закладає європейські основи розвитку галузі, у розрізі чого, ліквідовано поняття галузева стандартизація, адже такого поняття за межами нашої країни не існує. У подальшому, дотримання більшості нормативних документів та стандартів, відповідно до Угоди про асоціацію між Україною та ЄС ставатиме добровільним.

Зміни відбуваються не тільки у сфері видання та використання нормативної документації, але й у вітчизняному інституціональному середовищі всієї системи стандартизації. Так, у Свропейському Союзі національними органами зі стандартизації $є$ приватні структури, а в Україні - держава. 31993 по 2002 рр. національним органом стандартизації був Державний комітет стандартизації, метрології та сертифікації України (Держстандарт України), а в галузі будівництва - Мінбудархітектури України. Держстандарт був правонаступником Комітету України по стандартизації, метрології та сертифікації і Державного комітету України у справах захисту прав споживачів. У 2002 р. Держстандарт відповідним Указом Президента перетворений у Держспоживстандарт, або Державний комітет України з питань технічного регулювання та споживчої політики. Держспоживстандарт, на той час, став спеціально уповноваженим центральним органом виконавчої влади у сфері захисту прав споживачів, стандартизації, метрології та підтвердження відповідності. У ході адміністративної реформи 2011 р. Держспоживстандарт ліквідовується, а на його базі створюється Держспоживінспекція України (Державна інспекція України з питань захисту прав споживачів) [9, 19]. При цьому стандартизацію було вилучено як із назви, так і з безпосередніх основних функцій. Так, на Держспоживінспекцію України покладаються функції 3 реалізації державної політики 3 питань державного контролю у сфері захисту прав споживачів. Відповідно до нового закону «Про стандартизацію» та відповідного Розпорядження Кабінету Міністрів України, 32014 р. функції національного органу стандартизації виконує Державне Підприємство «Український науково-дослідний i навчальний центр проблем стандартизації, сертифікації та якості» (УкрНДНЦ) [9, 20].

Сьогодні, центральним органом виконавчої влади у сфері стандартизації України є Міністерство розвитку економіки, торгівлі та сільського господарства (до 2019 р. - Міністерство економічного розвитку i торгівлі України), одним із завдань якого є реалізація державної політики у сфері технічного регулювання - стандартизації, метрології, сертифікації, оцінки (підтвердження) відповідності, управління якістю [21].

Нормативні документи 3 стандартизації розподіляють за такими категоріями:

1. Державний стандарт України (ДСТУ). Державний стандарт України представляє собою документ, що встановлює правила, принципи або характеристики для загального і багаторазового застосування, які стосуються діяльності чи іiі результатів. ДСТУ затверджується Державним підприємством «Український науково-дослідний і навчальний центр проблем стандартизації, сертифікації та якості» (ДП «УкрНДНЦ»). Усі підприємства, що знаходяться на території України, незалежно від форм власності і підпорядкування, застосовують у своїй діяльності державні стандарти України [21].

2. Галузеві стандарти України (ГСТУ). Даний вид стандартів є подібним ДСТУ, але розробляється на товари лише у випадках відсутності на них ДСТУ чи у разі необхідності встановлення вимог, які перевищують або доповнюють вимоги державних стандартів [21].

3. Стандарти науково-технічних та інженерних товариств $і$ спілок України (СНТІСУ). Даний тип стандартів $є$ добровільним. Він розробляється підприємствами, які вважають доцільним використовувати нові передові засоби, технології та методи. Використання цих стандартів можливе лише за згодою замовника (споживача) [21].

4. Технічні умови Украӥни (ТУУ). Технічні умови - нормативний документ, який розробляється для встановлення вимог до якості товарів у випадку, коли ДСТУ чи ГСТУ на цей товар відсутні, або в разі необхідності конкретизації їх вимог [21].

5. Стандарти організації Украӥни (СОУ). Розробляють на товари або послуги, які виробляють та застосовують (здійснюють, надають) лише на конкретному підприємстві [21].

Крім зазначених, до категорії нормативних документів зі стандартизації потрібно віднести: міждержавні стандарти, регіональні стандарти, міжнародні стандарти (ISO), національні стандарти інших країн.

До органів державної служби стандартизації України відносяться [14, 21]:

1) Державне підприємство «Украӥнський науково-дослідний і навчальний иентр проблем стандартизачіï, сертифікаиії та якості» (ДП «УкрНДНЦ») [22]. ДП «УкрНДНЦ» надає можливість безкоштовно ознайомитись 3 стандартами у читальній залі Національного фонду нормативних документів. Установа також розповсюджує офіційні копії національних нормативних документів на паперових носіях, в електронному вигляді, через інтернет-магазин (shop.uas.org.ua) та на індивідуальне замовлення.

2) Державне підприємство «Науководослідний інститут метрологї вимірювальних і управляючих систем» (ДП НДІ «Система») засноване у 1968 р. Інститут є державним науковим метрологічним центром, що входить у державну метрологічну службу Департаменту технічного регулювання Міністерства економічного розвитку і торгівлі України [23].

У 1997-2000 рр. ДП НДІ «Система» було акредитовано як Орган сертифікації товарів, послуг та систем якості та призначено організаційно-методичним центром із сертифікації туристичних та готельних послуг, а також акредитовано на право проведення державних приймальних випробувань метрологічної атестації, повірки, калібрування інформаційновимірювальних систем (BIC) та інших засобів вимірювальної техніки. 
Співробітники інституту проводять дослідження та надають послуг у галузі оцінки відповідності. Зокрема, в ДП НДІ «Система» працює науковометодичний центр сертифікації готельних послуг, та в рамках його діяльності проводиться навчання та перепідготовка кадрів, а також надаються консультації $з$ сертифікації готельних послуг. Науково-методичний центр Інституту організовує і проводить семінари 3 підвищення якості готельних послуг та впровадження систем управління якістю, у першу чергу, для керівників готельних підприємств та для аудиторів 3 сертифікації готельних послуг системи УкрСЕПРО [24].

3) Державне підприємство «Всеукраїнський державний науково-виробничий иентр стандартизаиіï, метрології, сертифікації та захисту прав споживачів» (ДП «Укрметртестстандарт») створено 3 метою виконання державних функцій у сфері стандартизації, метрології, сертифікації, підтвердження відповідності, управління якістю, державного нагляду за додержанням стандартів, норм і правил та державного метрологічного контролю та нагляду згідно 3 вимогами чинного законодавства [25].

Предметом діяльності Центру є [25]:

- здійснення державного нагляду за додержанням стандартів, норм і правил на виробництво товарів народного споживання;

здійснення державного метрологічного контролю та нагляду згідно з чинним законодавством України;

здійснення наукових, науково-технічних та науково-організаційних робіт в сфері метрології, підтвердження відповідності та стандартизації, а також координуючої та науково-методичної діяльності серед підприємств, організацій та установ, незалежно від форм власності та виду діяльності;

- $\quad$ надання платних послуг у сфері стандартизації, метрології, сертифікації, підтвердження відповідності, управління якістю суб'єктам господарювання та фізичним особам, які не є суб'єктами господарювання.

4) Технічні комітети зі стандартизації (TK). Дані Комітети створено, у першу чергу, для організації та забезпечення розробки, розгляду, експертизи, погодження і підготовки до затвердження державних стандартів України, інших нормативних документів зі стандартизації, а також проведення робіт з регіонального та міжнародній стандартизації. До роботи в технічних комітетах стандартизації залучаються уповноважені представники органів виконавчої влади, інших державних органів, органів місцевого самоврядування, суб'єктів господарювання та їх громадських об'єднань, організацій роботодавців та їх об'єднань, наукових установ та навчальних закладів, науково-технічних та інженерних товариств (спілок), громадських організацій споживачів (об'єднань споживачів), інших громадських об'єднань, професійних спілок, провідні науковці і фахівці [26].

3 метою забезпечення ефективного доступу українських виробників та споживачів до міжнародних, міждержавних і національних нормативних документів створено Національний автоматизований інформаційний фонд стандартів. Нормативні документи цього фонду використовуються в усіх галузях суспільного виробництва та споживання товарів (надання послуг) [20]. У Національному автоматизованому інформаційному фонді стандартів зберігається понад 100 тис. нормативних документів, перелік яких постійно поновлюється. Працює міжнародна бібліографічна електронна база даних PERINORM [27]. Ознайомитися 3 необхідними інформаційними матеріалами стандартів Свропейського Союзу можна у існуючій повнотекстій автоматизованій базі даних.

3 90-х років минулого сторіччя, Україна входить у низку міжнародних та міждержавних організаціях з питань стандартизації, а саме [28]:

- Міждержавну Раду зі стандартизації, метрології та сертифікації країн СНД (3 1992 р.) [29];

- Міжнародну організацію зі стандартизації (ISO) та Міжнародну електротехнічну комісію (IEC) (3 1993 р.) [14, 30];

- Свропейський комітет зі стандартизації (CEN) та Міжнародну організацію законодавчої метрології (OIML) (3 1997 р.) [31, 32];

- Робочу групу з питань стандартизації Свропейської економічної комісії (СЕК) ООН [33];

- Організацію державних метрологічних комітетів ISO, а саме Комітету з інформаційних систем і послуг (INFCO) та Комітету з оцінки відповідності (CASCO) [14];

(ISONET) [34].

$$
\text { - Міжнародну інформаційну мережу }
$$

\section{Висновки та перспективи подальших дос-} ліджень. Узагальнення результатів дослідження дало можливість визначити стан сучасної системи стандартизації в Україні. Можна говорити про те, що зараз, вітчизняна система стандартизації, протягом історії трансформувалася, поліпшувалась та розширювалась, й сьогодні $\epsilon$ досить потужною та розгалуженою та має можливість охопити усі сфери виробництва та споживання товарів народного споживання. Отже на сьогодні в Україні є всі умови для виробництва конкурентоспроможних товарів, які будуть максимально відповідати вимогам споживачі та бути якісними. Подальші дослідження передбачають більш детальний аналіз нормативних документів, а саме безпосередньо стандартів, іх кількісного та якісного складу, й відповідності міжнародним умовам.

\section{Література}

1. Калюжна I.Ю., Гвоздецька І.В. Конкурентоспроможний товар - основа успішного виходу на зовнішній ринок // Вісник Хмельницького національного університету. Економічні науки. 2014. № 3(2). С. 146149.

2. Цилюрик Г.І. Якість товару - ключовий важіль забезпечення його конкурентоспроможності // Фінанси і облік України. 2008. № 3. С. 42-45 
3. Сукач М. Основи стандартизації. 2-ге видання, перероб. і доп. К.: Видавництво Ліра-К, 2017. 324 с.

4. Тарасова В., Малиновский А. Метрологія, стандартизація і сертифікація. М.: Рибак, 2006. 264 с.

5. Шемет А.Д. Стандартизація як метод регулювання якості товарів: її використання для інноваційних форм торгівлі. URL: http://www.nbuv.gov.ua/portal/ Soc_Gum/ Dtr_ep/2011_1/files/EC111_35.pdf. (дата 3верненення 10.10.2019)

6. Салухіна Н.Г., Язвінська О.М. Стандартизація та сертифікація товарів і послуг. К.: Центр учбової літератури, 2010. $336 \mathrm{c}$.

7. Боднар О. В. Стандартизація і сертифікація як методи забезпечення якості продукції // Науковий вісник Національного університету біоресурсів і природокористування України. 2013. Вип. 181. Ч. 1. С. $138-144$.

8. Дятлова В.В., Вознюк С.В. Система технічного регулювання в Україні: етапи і механізми трансформації // Вісник Донбаської державної машинобудівної академії. 2013. № 2 (31). С. 144-148.

9. Гарасим Ю. Й. Аналіз національної системи стандартизації і сертифікації у контексті угоди про асоціацію України та ЄС / Ю. Й. Гарасим // Зовнішня торгівля: економіка, фінанси, право. - 2015. - № 3. - С. 58-65.

10. Нагорна О.О. Система технічного регулювання як складова інноваційного розвитку економіки України // Електронне наукове фахове видання «Ефективна економіка». 2014. № 6. URL: http://www.economy.nayka.com.ua/?op=1\&z=3145 (дата зверненення: 5.10.2019)

11. Оносова I. А., Бровко О.Г. Порівняльна характеристика системи стандартів якості пшениці в Україні та країнах ЄС // Прогресивні техніка та технології харчових виробництв ресторанного господарства і торгівлі. 2012. Вип. 2. С. 190-198.

12. Литвинська С. Гармонізація українських національних стандартів серії "Інформація та документація" з міжнародними і європейськими: здобутки і перспективи // Ukrainian Scientific Journal of Information Security. 2012. № 2. C. 43-47.

13. Терера В., Нелепов А., Цицилиано А. Гармонизация нормативной базы на основе современных международных и европейских стандартов // Стандартизация, сертификация, качество. 2008. № 3. С. 40-46. doi: 10.1249/01.mss.0000320994.34045.b5

14. International Organization for Standardization: web-site. URL: https://www.iso.org/home.html. (дата зверненення: 1.10.2019)

15. Про стандартизацію: Закон України від 05.06.2014 № 1315-VII за станом на 03.07.2019 р. // Законодавство України: веб-сайт. URL: https://zakon.rada.gov.ua/laws/show/1315-18. (дата зверненення: 1.10.2019)

16. Угода про асоціацію між Україною та Європейським союзом. Урядовий портал: веб-сайт. URL: https://zakon.rada.gov.ua/laws/show/984_011 (дата зверненення: 5.10.2019)

17. Угода про асоціацію між Уекраїною та СС: наслідки для бізнесу, населення та державного управління: звіт Інституту економічних досліджень i політичних консультацій. URL: http://www.ier.com.ua/files/projects/2013/eu_ukraine/report_version_for_public_debates_2013-07-01.pdf (дата 3верненення: 5.10.2019)

18. Наказ Міністерства економічного розвитку і торгівлі України № 1493 «Про прийняття європейських та міжнародних нормативних документів як національних стандартів України, змін до національних стандартів України та скасування національних стандартів України» від 30 грудня 2014 р. // Законодавство України: вебсайт. URL: https://zakon.rada.gov.ua/rada/show/ru/v1493731-14 (дата зверненення: 10.10.2019)

19. Указ Президента України «Про положення про державну інспекцію України з питань захисту прав споживачів» від 13 квітня 2011 року №465/2011 // Законодавство України: веб-сайт. URL: https://zakon.rada.gov.ua/laws/show/465/2011 (дата зверненення: 5.10.2019)

20. Розпорядження КМУ від 26 листопада 2014 р. № 1163-р «Про визначення державного підприємства, яке виконує функції національного органу стандартизації» // Законодавство України: веб-сайт. URL:http://zakon4.rada.gov.ua/laws/show/1163-2014-\%D1\%80 (дата зверненення 7.10.2019)

21. Національна стандартизація. Основні положення: веб-сайт. URL: https://dnaop.com/html/44088/doc\%D0\%94\%D0\%A1\%D0\%A2\%D0\%A3_1.0_2003 (дата зверненення: 7.10.2019)

22. Державне підприємство «Український науково-дослідний і навчальний центр проблем стандартизаціï, сертифікації та якості» (ДП «УкрНДНЦ»): веб-сайт. URL: http://uas.org.ua/ua. (дата зверненення: 5.10.2019)

23. Державне підприємство «Науково-дослідний інститут метрології вимірювальних і управляючих систем» (ДП НДІ «Система»): веб-сайт. URL: https://www.dndi-systema.lviv.ua/node (дата зверненення: 5.10.2019)

24. УкрСЕПРО: веб-сайт. URL: http://ukrsepro.kiev.ua / (дата зверненення: 5.10.2019)

25. Державне підприємство «Всеукраїнський державний науково-виробничий центр стандартизації, метрології, сертифікації та захисту прав споживачів» (ДП «Укрметртестстандарт»): веб-сайт. URL: http://www.ukrcsm.kiev.ua/index.php/en/. (дата зверненення: 5.10.2019)

26. The general agreement on tariffs and trade. URL: https://www.wto.org/english/docs_e/legal_e/gatt47.pdf. (viewed on: 7.10.2019) (дата зверненення: 7.10.2019)

27. Міністерство закордонних справ України. Єдиний державний реєстр Міжнародних організацій, членом яких є Україна. URL: https://mfa.gov.ua/ua/about-ukraine/international-organizations/io-register (дата зверненення: 7.10.2019) 
28. Міністерство економічного розвитку і торгівлі України. Національне агентство з акредитації України. Міждержавна рада зі стандартизації, метрології та сертифікації (МДР) Співдружності Незалежних Держав (СНД) URL: https://naau.org.ua/mizhnarodna-diyalnist/spivrobitnictvo-z-mdr/ (дата зверненення: 5.10.2019)

29. International Electrotechnical Commission: web-site. URL: https://www.iec.ch/ (viewed on: 5.10.2019)

30. European committee for standardization: web-site. URL: https://www.cen.eu (viewed on: 5.10.2019) 5.10.2019)

31. International Organization of Legal Metrology: web-site. URL: https://www.oiml.org/en (viewed on:

32. United Nations Economic Commission for Europe (UNECE): web-site. URL: http://www.unece.org/info/ece-homepage.html (viewed on: 5.10.2019)

33. Положення про Національний інформаційний центр із стандартизації та сертифікації Міжнародної інформаційної мережі ISONET. URL: https://zakon.rada.gov.ua/laws/show/z0262-95 (viewed on: 5.10.2019)

Стаття надійшла 15.10.2019

Стаття прийнята до друку 29.10.2019

Доступно в мережі Internet 26.12.2019

\author{
Кордзая H.P. \\ кандидат технических наук, доцент \\ кафедра маркетинга, предпринимательства и торговли \\ E-mail: natela k@ukr.net \\ ORCID ID: 0000-0003-3429-0483 \\ Егоров Б.В. \\ доктор технических наук, профессор \\ кафедра технологии комбикормов и биотоплива \\ Одесская национальная академия пищевых технологий \\ ул. Канатная, 112, г. Одесса, Украина, 65039 \\ E-mail: bogdanegoroff58@gmail.com \\ ORCID ID: 0000-0001-7526-0315
}

\title{
ИНСТИТУЦИОНАЛЬНАЯ СТРУКТУРА ОТЕЧЕСТВЕННОЙ СИСТЕМЫ СТАНДАРТИЗАЦИИ ТОВАРОВ
}

В работе рассмотрены основные понятия системы стандартизации в Украине. Цель исследования - анализ особенностей функционирования национальной системы стандартизации товаров народного потребления как основы ее конкурентоспособности. Сегодня, благодаря стандартизации производители могут сознательно управлять качеством производимой товаров, а, следовательно, и ее конкурентоспособностью на современном рынке, а потребители в свою очередь могут контролировать и проверять это качество, что в особенности касается пищевых продуктов и сырья. В исследовании дано определение терминов «стандартизация» и «стандарт». Приведена классификация нормативных документов по стандартизации, существующих в Украине. Среди них выделены и охарактеризованы следующие: государственные стандарты Украины (ДСТУ), отраслевые стандарты Украины (ГСТУ), стандарты научно-технических и инженерных обществ и союзов Украины (СНТИСУ), технические условия Украины (ТУ), технические условия, стандарты организации Украины (СОУ). Кроме того, приведен перечень органов государственной службы стандартизации Украины и рассмотрены особенности их фрункционирования. К данным органам относятся следующие: государственное предприятие «Украинский научно-исследовательский и учебный центр проблем стандартизации, сертификации и качества», государственное предприятие «Научно-исследовательский институт метрологии измерительных и управляющих систем», государственное предприятие «Всеукраинский государственный научно-производственный центр стандартизации, метрологии, сертификации и защиты прав потребителей» и технические комитеты по стандартизации. Дана характеристика работе национального автоматизированного информационного фонда стандартов и особенностях функционирования международной библиографической электронной базы данных PERINORM в Украине. Также в работе приведены международные и межгосударственные организации по стандартизации, в которые входит Украина.

Ключевые слова: продовольственная безопасность, качество, конкурентоспособность, стандартизация, нормативный документ. 


\author{
Kordzaia N. \\ Ph.D, Associate Professor \\ Department of Marketing, Entrepreneurship and Trade \\ Email: natela k@ukr.net \\ ORCID ID: 0000-0003-3429-0483 \\ Yegorov B. \\ Doctor of Technical Sciences, Professor \\ Department of Mixed Feeds and Biofuel Technology \\ Odessa National Academy of Food Technologies \\ st. Kanatna, 112, Odessa, Ukraine, 65039 \\ Email: bogdanegoroff58@gmail.com \\ ORCID ID: 0000-0001-7526-0315
}

\title{
INSTITUTIONAL STRUCTURE OF DOMESTIC SYSTEM OF COMMODITY STANDARDIZATION
}

The basic concepts of a standardization system in Ukraine have been considered in the work. Today, due to standardization, manufacturers can consciously control their products quality, and, consequently, competitiveness of these products on the modern market. And consumers can control and verify their quality, especially food products and raw materials. The study provides a definition of the terms "standardization" and "standard". The classification of normative documents on standardization existing in Ukraine has been given. Among them, the following documents were highlighted and characterized: state standards of Ukraine (DSTU), industry standards of Ukraine (GSTU), standards of scientific, technical and engineering societies and unions of Ukraine (SNTISU), technical conditions of Ukraine (TU), technical conditions, standards of organization of Ukraine (SOU). In addition, a list of public service standards bodies of Ukraine is given. The features of their functioning have been considered. These bodies include the following: state-owned enterprise "Ukrainian Research and Training Center for Standardization, Certification and Quality Problems", state-owned enterprise "Research Institute of Metrology of Measurement and Control Systems", state-owned enterprise "All-Ukrainian State Research and Production Center for Standardization, Metrology, Certification and Consumer protection" and technical committees for standardization. The characteristic of the work of the national automated information fund of standards and the functioning of the international bibliographic electronic database PERINORM in Ukraine has been given. Also, the work lists international and interstate standardization organizations, which include Ukraine.

Key words: food safety, quality, competitiveness, standardization, normative document.

\section{References}

1. Kaliuzhna, I. Yu., \& Hvozdetska, I. V. (2014). Konkurentospromozhnyi tovar - osnova uspishnoho vykhodu na zovnishnii rynok. Visnyk Khmelnytskoho Natsionalnoho Universytetu. Ekonomichni Nauky, (3 (2)), 146-149.

2. Tsyliuryk, H. I. (2008). Yakist tovaru - kliuchovyi vazhil zabezpechennia yoho konkurentospromozhnosti. Finansy i Oblik Ukrainy, (3), 42-45.

3. Sukach, M. (2017). Osnovy standartyzatsii (2 vydannia, pererob. i dop.). Kyiv: Vydavnytstvo Lira-K.

4. Tarasova, V., \& Malynovskyi, A. (2006). Metrolohiia, standartyzatsiia i sertyfikatsiia. Moscow: Rybak.

5. Shemet, A. D. (2011). Standartyzatsiia yak metod rehuliuvannia yakosti tovariv: yii vykorystannia dlia innovatsiinykh form torhivli. Retrieved October 10, 2019, from http://www.nbuv.gov.ua/portal/ Soc_Gum/ Dtr_ep/2011_1/files/EC111_35.pdf.

6. Salukhina, N. H., \& Yazvinska, O. M. (2010). Standartyzatsiia ta sertyfikatsiia tovariv i posluh. Kyiv: Tsentr uchbovoi literatury.

7. Bodnar, O. V. (2013). Standartyzatsiia i sertyfikatsiia yak metody zabezpechennia yakosti produktsii. Naukovyi Visnyk Natsionalnoho Universytetu Bioresursiv i Pryrodokorystuvannia Ukrainy, (181, Ch. 1.), 138-144.

8. Diatlova, V. V., \& Vozniuk, S. V. (2013). Systema tekhnichnoho rehuliuvannia v Ukraini: etapy i mekhanizmy transformatsii. Visnyk Donbaskoi Derzhavnoi Mashynobudivnoi Akademii, (2 (31), 144-148.

9. Harasym, Yu. Y. (2015). Analiz natsionalnoi systemy standartyzatsii i sertyfikatsii u konteksti uhody pro asotsiatsiiu Ukrainy ta YeS. Zovnishnia Torhivlia: Ekonomika, Finansy, Pravo, (3), 58-65.

10. Nahorna, O. O. (2014). Systema tekhnichnoho rehuliuvannia yak skladova innovatsiinoho rozvytku ekonomiky Ukrainy. Elektronne Naukove Fakhove Vydannia «Efektyvna Ekonomika», (6). Retrieved October 05, 2019, from http://www.economy.nayka.com.ua/?op=1\&z=3145 
11. Onosova, I. A., \& Brovko, O. H. (2012). Porivnialna kharakterystyka systemy standartiv yakosti pshenytsi v Ukraini ta krainakh YeS. Prohresyvni Tekhnika Ta Tekhnolohii Kharchovykh Vyrobnytstv Restorannoho Hospodarstva i Torhivli, (2), 190-198.

12. Lytvynska, S. (2012). Harmonizatsiia ukrainskykh natsionalnykh standartiv serii "Informatsiia ta dokumentatsiia" z mizhnarodnymy i yevropeiskymy: zdobutky i perspektyvy. Ukrainian Scientific Journal of Information Security, (2), 43-47.

13. Terera, V., Nelepov, A., \& Tsitsiliano, A. (2008). Garmonizatsiya normativnoy bazyi na osnove sovremennyih mezhdunarodnyih i evropeyskih standartov. Standartizatsiya, Sertifikatsiya, Kachestvo, (3), 40-46. doi: 10.1249/01.mss.0000320994.34045.b5

14. International Organization for Standardization. (n.d.). Retrieved October 1, 2019, from https://www.iso.org/home.html

15. Pro standartyzatsiiu: Zakon Ukrainy vid 05.06.2014 № 1315-VII za stanom na 03.07.2019 r. (2019). Retrieved October 1, 2019, from https://zakon.rada.gov.ua/laws/show/1315-18

16. Uhoda pro asotsiatsiiu mizh Ukrainoiu ta Yevropeiskym soiuzom. (2017). Retrieved October 5, 2019, from https://zakon.rada.gov.ua/laws/show/984_011

17. Uhoda pro asotsiatsiiu mizh Ukrainoiu ta YeS: naslidky dlia biznesu, naselennia ta derzhavnoho upravlinnia: zvit Instytutu ekonomichnykh doslidzhen i politychnykh konsultatsii. Retrieved October 5, 2019, from http://www.ier.com.ua/files/projects/2013/eu_ukraine/report_version_for_public_debates_2013-07-01.pdf.

18. Nakaz Ministerstva ekonomichnoho rozvytku i torhivli Ukrainy № 1493 «Pro pryiniattia yevropeiskykh ta mizhnarodnykh normatyvnykh dokumentiv yak natsionalnykh standartiv Ukrainy, zmin do natsionalnykh standartiv Ukrainy ta skasuvannia natsionalnykh standartiv Ukrainy» vid 30 hrudnia 2014 r. (2014). Retrieved October 10, 2019 , from https://zakon.rada.gov.ua/rada/show/ru/v1493731-14

19. Ukaz Prezydenta Ukrainy «Pro polozhennia pro derzhavnu inspektsiiu Ukrainy z pytan zakhystu prav spozhyvachiv» vid 13 kvitnia 2011 roku №465/2011. (2012). Retrieved October 5, 2019, from https://zakon.rada.gov.ua/laws/show/465/2011

20. Rozporiadzhennia KMU vid 26 lystopada 2014 r. № 1163-r «Pro vyznachennia derzhavnoho pidpryiemstva, yake vykonuie funktsii natsionalnoho orhanu standartyzatsii». (2015). Retrieved October 7, 2019, from http://zakon4.rada.gov.ua/laws/show/1163-2014-p

21. Natsionalna standartyzatsiia. Osnovni polozhennia. (2003). Retrieved October 7, 2019, from https://dnaop.com/html/44088/doc-ДСТУ_1.0_2003

22. Derzhavne pidpryiemstvo «Ukrainskyi naukovo-doslidnyi i navchalnyi tsentr problem standartyzatsii, sertyfikatsii ta yakosti» (DP «UkrNDNTs»). Retrieved October 5, 2019, from http://uas.org.ua/ua

23. Derzhavne pidpryiemstvo «Naukovo-doslidnyi instytut metrolohii vymiriuvalnykh i upravliaiuchykh system» (DP NDI «Systema»). Retrieved October 5, 2019, from https://www.dndi-systema.lviv.ua/node

24. UkrSEPRO. Retrieved October 5, 2019, from http://ukrsepro.kiev.ua/

25. Derzhavne pidpryiemstvo «Vseukrainskyi derzhavnyi naukovo-vyrobnychyi tsentr standartyzatsii, metrolohii, sertyfikatsii ta zakhystu prav spozhyvachiv» (DP «Ukrmetrteststandart»). Retrieved October 5, 2019, from http://www.ukrcsm.kiev.ua/index.php/en/

26. The general agreement on tariffs and trade. Retrieved October 5, 2019, from https://www.wto.org/english/docs_e/legal_e/gatt47.pdf

27. Ministerstvo zakordonnykh sprav Ukrainy. Yedynyi derzhavnyi reiestr Mizhnarodnykh orhanizatsii, chlenom yakykh ye Ukraina. Retrieved October 7, 2019, from https://mfa.gov.ua/ua/about-ukraine/internationalorganizations/io-register

28. Ministerstvo ekonomichnoho rozvytku i torhivli Ukrainy. Natsionalne ahentstvo z akredytatsii Ukrainy. Mizhderzhavna rada zi standartyzatsii, metrolohii ta sertyfikatsii (MDR) Spivdruzhnosti Nezalezhnykh Derzhav (SND). Retrieved October 5, 2019, from https://naau.org.ua/mizhnarodna-diyalnist/spivrobitnictvo-z-mdr/

29. International Electrotechnical Commission. Retrieved October 5, 2019, from https://www.iec.ch/

30. European committee for standardization. Retrieved October 5, 2019, from https://www.cen.eu

31. International Organization of Legal Metrology. Retrieved October 5, 2019, from https://www.oiml.org/en

32. United Nations Economic Commission for Europe (UNECE). Retrieved October 5, 2019, from http://www.unece.org/info/ece-homepage.html

33. Polozhennia pro Natsionalnyi informatsiinyi tsentr iz standartyzatsii ta sertyfikatsii Mizhnarodnoi informatsiinoi merezhi ISONET. (1995). Retrieved October 5, 2019, from https://zakon.rada.gov.ua/laws/show/z0262-95

Received 15 October 2019

Approved 29 October 2019

Цитування згідно ДСТУ 8302:2015 Available in Internet 26.12.2019

Кордзая Н.Р., Сгоров Б.В. Інституціональна структура вітчизняної системи стандартизації товарів // Економіка харчової промисловості. 2019. Т.11, вип. 4. С. 80-87. doi: 10.15673/fie.v11i4.1550

Cite as APA style citation

Kordzaia, N., \& Yegorov, B. (2019). Institutional structure of domestic system of commodity standardization. Food Industry Economics, 11(4), 80-87. doi: 10.15673/fie.v11i4.1550 